\title{
THE IMPORTANCE OF INSTITUTIONAL INVESTORS DIVERSIFICATION IN THE DEVELOPMENT OF THE GOVERNMENT SECURITIES MARKET
}

\section{Rodica Hincu}

Faculty of Finance, Academy of Economic Studies, Chisinau, Republic of Moldova

\author{
Ana Litocenco \\ Faculty of Finance, Academy of Economic Studies, Chisinau, Republic of \\ Moldova \\ CMESTE \\ JEL Category: D47, G21, G23
}

\begin{abstract}
The development of a government securities market is a complex process that is interrelated with the financial and market system development of each country. For many countries, this implies huge challenges that often are amplified by economic issues. For instance, some government securities markets rely on a few domestic banks for funding, which makes competition scarce, and transaction costs high. In addition to this, the lack of a sound market infrastructure may make specific actions to develop a government securities market premature and ineffective. At the same time, the insufficiency of institutional investors, low domestic savings rates, and lack of interest from international investors generate a small, highly homogeneous investor group, contrary to the diversity needed for an efficient market. Furthermore, economic instability, often accompanied by high fiscal deficits, rapid growth of the money supply, and a deteriorating exchange rate, weakens investor confidence and increases the risks associated with the development of a market for government securities. This article aims to describe the importance of a diversified investor base in developing a government securities market and to show the experience of the Republic of Moldova in this regard.
\end{abstract}

Keywords: government securities, market development, state policy, institutional investors, banks, insurance companies, pension funds, investment funds, individual investors

The address of the corresponding author Rodica Hincu

夆=”rodica.hincu3@gmail.com

\section{INTRODUCTION}

The situations of a deficient budget balance at a certain stage in time impose the need for the state to develop alternative sources of financing to ensure efficient management of public finances capable of providing financial coverage to the 
economic sectors. One of these alternative sources of financing is the government securities market (GS). The prerequisites for the development of an efficient GS market are a stable and credible government, adequate fiscal and monetary policies, tax infrastructure, efficient justice and regulators, and a liberalized and welldeveloped financial system. Both domestic and foreign investors are reluctant to purchase/ invest in GS, especially medium- and long-term instruments when in the economy is expected high inflation, significant devaluations, or considerable risks of default. Thus, the existence of a macroeconomic policy framework with a credible commitment to prudent, sustainable, and stable fiscal and monetary policies reduces government financing costs in the medium and long term.

However, these measures are not sufficient to ensure the efficient development and functioning of the GS market. Government securities, like any other product, require buyers, and the state must identify and apply the measures that lead to stimulating demand for the securities issued.

To assure government funding, over time, many states have taken advantage of their powers, including from a fiscal and prudential point of view, to secure the demand for GS issued, which often results in situations when financial institutions were forced to finance the government financial needs given the imposed prudential and liquidity requests.

This practice has not always achieved its goal of reducing the cost of financing, and one of the results of this forced financing has been economic inefficiency given the misallocation of resources and obtaining lower interest rates than market interest rates. Although most developed countries have abandoned this practice of forcing financial institutions to procure GS, in some developing countries it is still a key element in financing budgetary needs.

An alternative to this flawed practice, increasingly used by developed countries, is to form a volunteer investor base. Thus, through appropriate reform, licensing, regulatory and supervision programs, some states are increasingly encouraging the development of wholesale investors and other entities investing in GS for revenue, hedging, or repo transactions. At the same time, some developed countries are also interested in developing a retail investor base for issued GS, with its expansion and diversification by opening the market for foreign investment.

A diversified investor base in GS, with different trading horizons and risk preferences, contributes significantly to ensuring high liquidity and stable market demand. On the other hand, even liquid markets may become illiquid in periods when a single group of investors leaves or enters the market in a short time and where there is no balancing of flows from other groups of investors.

Therefore, the state, as the issuer of the GS, must understand the factors that generate interest in their product, identify the investment groups in the market, develop types of instruments with characteristics that match those sought/expected by different types of investors, as well as to organize massive campaigns for their promotion/marketing. Stimulating demand for GS is as important as developing market infrastructure to ensure an efficient transaction. At the same time, through its policies, the state must reorient itself from forcing investors to keep their assets in GS, to interesting them in voluntary investments.

The benefits of diversifying investors on the GS market are the following:

- $\quad$ reducing the costs of financing state debt.

- $\quad$ ensuring the stability and efficiency of the GS market.

- increasing the financing capacity of the national economy's needs.

- fostering the emergence and use of financial technologies and innovations.

Potential investors in the GS market are grouped into 2 major categories: domestic investors and foreign investors. These 2 categories, in turn, are divided into 2 other groups:

- financial investors - banks, insurance companies, pension funds, collective investment undertakings.

- non-financial investors - enterprises, nonfinancial institutions, and individual investors. 


\section{THE PARTICULARITIES \\ DIFFERENT \\ INVESTORS GOVERNMENT MARKET

TYPES OF
ON THE
SECURITIES

Regarding financial investors, one of the most important categories of investors in the GS market is commercial banks. These are institutional investors that invest in government bills, bonds, and other debt instruments to meet liquid asset requirements, obtain a stable interest income, manage efficiently their short-term liquidity. GS also represents an opportunity to hedge their interest rate positions and to provide collateral for repo transactions with customers and the borrowing relations with the central bank. Commercial banks have been in many countries the largest captive source of government funding. By setting high minimum reserve and liquid asset ratio requirements and ensuring that government securities are the only eligible assets that satisfy these requirements, governments have been able to borrow substantial amounts at below-market rates of interest. While commercial banks are a major investor source for GS, their strong presence in this market may reflect some fundamental shortcomings in their commercial banking operations. Heavy investments in GS by commercial banks may imply weaknesses in their primary function, which is lending. Such operating weaknesses as ineffective screening and monitoring capabilities of loans, uncertainty related to the creditworthiness of the borrowers and projects, and weak legal systems may determine the banks to find safeness in GS. Once these operating deficiencies are corrected, banks may become less significant holders of GS.

When it comes to pension funds and insurance companies, the main objective of the first one is to provide accessible and lasting benefits, and the second one is to offer efficient insurance products. The specific needs of these types of institutional investors are not limited to adequate profits and prudence. These investors are interested in greater transparency and market integrity, both primary and secondary market of GS. They need to ensure lower trading costs and efficient trading and settlement procedures. At the same time, these investors stimulate innovations both in terms of financial products and business practices, which are adapted to more efficient management and protection against risks.

Referring in particular to pension funds, in promoting policies aimed at activating their participation in the GS market, the state should pay attention to the general organization of the social security system and the roles of the public and private components, and those funded and unfunded. Thus, if within a state the system of compulsory private pensions is implemented (Pillar II) and a part of the contributions of the public retirement system will be administered by private entities, it must very carefully assess the costs of transition to this system to avoid exposing the public pension system to unsustainable financial obligations. The promotion of private pension funds (Pillar III) requires the application of a robust and effective regulatory framework that resembles the regulatory framework imposed on other types of financial institutions (banks, insurance companies, and investment funds). Given that pension plans involve long-term contracts that extend to 60 years or more, their regulatory and supervisory framework must be rigorous and effective. Regulations relating to the activity of pension funds should provide clear criteria for obtaining a license for the nonadmission of unqualified entities, the prudent diversification of assets/investments, the valuation of assets, the frequency of actuarial reviews and audits, and how to ensure transparency in the business.

Similar features apply to the development of the insurance sector. In the case of both pension funds and insurance companies, opening up the local markets to foreign investors and integrating them into global markets facilitates the transfer of financial technologies, efficient and prudent operation, and contributes to the capitalization of these institutions.

At the same time, it is important to note that in many countries, institutional investors are promoted through tax incentives. In the case of pension funds, tax incentives often involve tax exemptions on annual contributions and investment income, with retirement benefits taxed when received. This approach avoids double taxation of long-term savings and provides incentives for retirement savings. In the case of life insurance, similar incentives are sometimes 
offered for premiums paid for long-term life insurance products.

Another category of financial entities that may provide financing for the budgetary needs is the collective investment companies. These companies offer professional management and asset diversification with high liquidity and low cost. Some of the collective investment firms serve other institutional investors, but the vast majority focus on retail investors. The primary purpose of these entities is to invest in marketable securities-equities and bonds on behalf of the public. The collective investment funds are dependent on efficient and well-functioning GS markets. Unlike pension funds and insurance companies, which maintain well-diversified portfolios, investment funds are usually created with specialized investment objectives. They, therefore, consciously carry unbalanced portfolios, with a heavy concentration in bonds (either corporate or government) or equities (either diversified or sector-specific). In this context, investment funds play an active role in government markets and provide a good source of government funding. An interesting feature of this type of entity for developing countries is that their development does not depend on complex social security and insurance sector reforms. They can, therefore, grow fast, if they operate in a robust regulatory framework that promotes market integrity and protects the interests of small investors. Their rate of growth usually depends on the conditions supporting disintermediation from traditional bank products (bank deposits) to capital market instruments.

Concerning non-financial investors, taking into account the practice in many countries, nonfinancial corporations, such as commercial and industrial companies, are not investing in longterm GS, and are using this market only to effectively manage their liquid assets. When it comes to the individual investors, another category of non-financial investors, complying with the investment needs of individual investors is a key component in the diversification strategy of the GS market investor base, given that they are considered relatively stable holders of GS. However, the state must consider the operating and distribution costs of working directly with individual investors. In this context, banks appear in most states as intermediaries between the issuer of the GS and the institutional investor. Over time, many countries in the world (both developed and developing) have issued special products to individual investors, often called national savings certificates. The basic objective of these certificates is to encourage populationsaving skills, especially among people with limited access to financial institutions, but also to help finance the needs of the national economy. Savings certificates are usually sold through post offices or banks, with maturities not exceeding five years and with tax-exempt interest income. To encourage long-term investment, the interest rate increases in proportion to the duration of the certificate.

\section{THE INVESTOR BASE OF THE GOVERNMENT SECURITIES MARKET OF THE REPUBLIC OF MOLDOVA}

According to the national framework of the Republic of Moldova, as an investor on the internal GS market of the country may be any individual or legal person, resident or non-resident of the Republic of Moldova, on whose behalf the primary dealer submits the offer to participate in the GS auction of sale and/or performs transactions on the secondary market. The issuance of GS, as well as payments and transfers related to the GS purchase and redemption on the domestic market, are made only in national currency, and transactions are carried out only through primary dealers, which are represented by banks that have been accepted by the Ministry of Finance of the Republic of Moldova and have concluded agreements with the National Bank of Moldova to carry out GS operations on the domestic market as a result of meeting the selection criteria and which may conduct operations on behalf of itself or behalf of its clients (investors). At the same time, the Government of the Republic of Moldova issues GS instruments with a maturity of 5 years.

According to the statistical data published by the Ministry of Finance of the Republic of Moldova, a major part of the investments in the domestic GS market are made by the banking sector (see figure 1). 


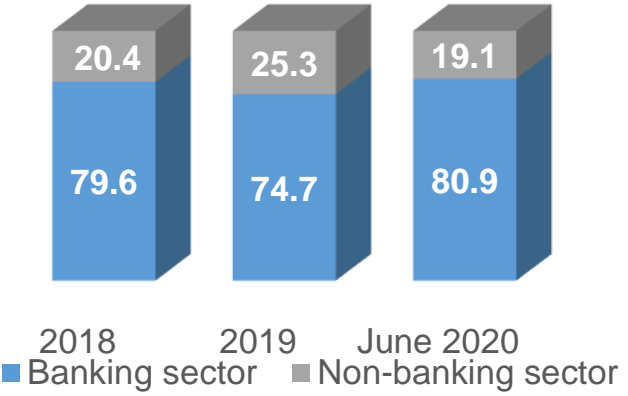

Figure 1. Types of investors holding government securities that were in circulation on the domestic primary market of the Republic of Moldova from 2018 to June 2020, [\%]

Source: Made by authors based on statistical data of the Ministry of Finance of the Republic of Moldova (www.mf.gov.md)

As of $30^{\text {th }}$ of June 2020 , around $81 \%$ (with 6.2 p.p. more comparing to the situation on $31^{\text {st }}$ of December 2019) of the GS that was in circulation on the GS domestic market of the Republic of Moldova were held by banks. Other 19\% were held by other entities that are outside the banking sector, and in 6 months of the current year, this proportion decreased. At the same time, in mid2020 only $0.03 \%$ of the total amount of GS available on the domestic market of the Republic of Moldova were held by non-resident investors.

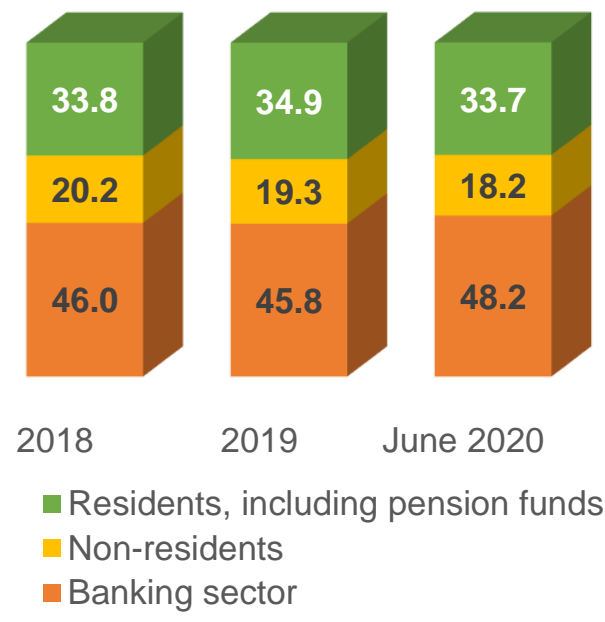

Figure 2. Types of investors holding government securities that were in circulation on the internal primary market of Romania from 2018 to June 2020, [\%]

Source: Made by authors based on statistical data of the Ministry of Public Finances of Romania (www.mfinante.gov.ro)
Comparing the investor base of the domestic GS market of the Republic of Moldova with the one in Romania (see figure 2), it may be concluded that the banking institutions in Romania are one the major investors as well in the domestic GS market of the country.

However, Romania has a more diversified investor base of the GS market, and other investors besides banks are quite active in investing in Romanian GS. About $1 / 3$ of the GS available on the domestic market as of $30^{\text {th }}$ of June 2020 were held by the residents. In the category of residents are included the pension funds as well, and these financial entities hold $19.4 \%$ of the GS domestic market of Romania. Non-resident investors hold roughly $1 / 5$ of the GS domestic market.

In Romania, the Government issues GS instruments both, in national and foreign currency, and their maturity can reach more than 15 years. At the same time, it is worth mentioning that Romania has developed and is implementing 2 Programs especially designated for individuals and their investment needs.

Under the $1^{\text {st }}$ Program, „Fidelis”, which was launched in 2015 and redeveloped in 2020, the subscription of the titles is done through the commercial banks, without charging certain commissions in this respect. At the same time, since this year, the GS may be issued in foreign currency (euro) as well. The maturity of these GS is 2 and 4 years for issuance in national currency with an interest rate of 4 and respectively $4.5 \%$, and 5 years - for issuance in euro, with an interest rate of $2 \%$.

The $2^{\text {nd }}$ Program, "Tezaur", was launched in 2018 and aims at assuring the accessibility of GS investment instruments all over the country, including in the rural regions. The subscription of the titles is made directly by the individuals at territorial State Treasury offices as well as at the post offices. GS available to the public under this Program have maturities of $1,2,3$, and 5 years, at an interest rate of $3.5 \%, 4 \%, 4.25 \%$, and $4.75 \%$, respectively. Both programs have proven to be of great success, individuals subscribing all the GS proposed by the Government for issuance.

In the Republic of Moldova, there are no savings programs based on GS available for individuals, 
and even if this category of nonfinancial investors is interested in investing in this type of instrument, it must apply to a bank (primary dealer). This procedure is quite difficult for individuals, especially for those from the rural zones, and therefore it makes Moldovan GS unattractive for them.

Regarding the financial investors on the domestic GS market of the Republic of Moldova, the strong presence of the banks is explained as in many countries by the prudential and liquidity requirements imposed by the regulatory framework of the National Bank of Moldova. Another reason is that the banks are the major players in the national financial market. The presence of other financial investors on the GS domestic market of the Republic of Moldova is quite modest due to the poor development of the financial market itself. Therefore, as a result of different assessments made by the World Bank, it was stated that the insurance market of the Republic of Moldova is fragile, underdeveloped (including with stagnation and vulnerabilities), to a significant extent dependent on payment obligations, and the insurance companies are facing the problem of low capitalization and weak position towards solvency requirements. The collective investment sector and pension funds are almost inexistent. Even if few entities were authorized by the regulators, they did not carry out any activity.

However, in the context of signing the Association Agreement with the European Union in 2014, the Republic of Moldova assumed the engagements to approach its national framework with the EU acquis. Thus, in the financial sector, the national authorities consolidated all the efforts to develop a new framework related to the insurance sector, pension funds, and collective investment.

Therefore, the necessary framework for collective investment entities was designed and adopted in 2012 (Law of the Republic of Moldova no. 171/2012 on the capital market) and it contains provisions related to instituting and performing the activity of collective investment companies in securities. Afterward, at the beginning of this year, the Parliament of the Republic of Moldova adopted a second Law on collective investment (Law no. 2/2020 on alternative collective investment entities) and it contains a rigorous regulation on establishing and functioning of the alternative investment funds (such as investment funds, venture funds). The Law transposed the following EU framework: The EU Directive 2011/61/UE on Alternative Investment Fund Managers; the Commission Delegated Regulation (EU) No 694/2014 supplementing Directive 2011/61/EU concerning regulatory technical standards determining types of alternative investment fund managers; the Regulation (EU) 2015/760 on European long-term investment funds; the Regulation (EU) 345/2013 on European venture capital funds.

Another policy reform that is in the process of being adopted by the Parliament of the Republic of Moldova is related to the pension funds. In Moldova, there are no compulsory private pensions (Pillar II) and there is no legal framework related to it. However, the authorities have prepared the necessary framework for the Pillar III pension system since 1999, under which were authorized few pension funds that did not perform any activity. According to the Association Agreement, the Moldovan authorities have drafted a new Law on private pension funds that transposed the provisions of the Directive (UE) $2016 / 2341$ on the activities and supervision of institutions for occupational retirement provision (IORPs). The Law was approved by the Government of the Republic of Moldova on the $10^{\text {th }}$ of June this year and was examined in the First Reading of the Parliament on the $9^{\text {th }}$ of July 2020.

The insurance sector of the Republic of Moldova is also passing a period of policy reforms. With the support of the World Bank, the national authorities have drafted a new Law on insurance and reinsurance and exposed it for public consultations at the beginning of this year. The draft is transposing the provisions of the Solvency II Directive (Directive 2009/138/EC on the takingup and pursuit of the business of Insurance and Reinsurance). The draft is expected to be adopted by the end of this year. However, due to the weak level of insurance market development in the Republic of Moldova, the new Law on insurance is not transposing the quantitative (capital and solvency) requirements of the Directive. These requirements will be transposed and applicable after an evaluation of the insurance companies and after consolidating the market. 
By drafting all this new framework, the Moldovan authorities aim to implement the best practices and international standards related to the activity on the financial market. The new Laws in comparison to those that existed previously come with several innovative elements and more rigorous regulations on some issues, especially those related to:

- the organization, functioning, and regulation of the activity - the new Laws provide more complex regulations on the mandatory requirements that need to be met by the entities (administrators, depositors, members of their governing bodies, prohibitions in activity, situations when the financial entity may not act without the regulations permission/ approval), as well as the levers/instruments of the intervention of the regulator in the process of supervising the activity. Also, there are clear regulations on the need of establishing internal control and risk assessment functions, as well as the obligation of the financial entities to conduct a periodical external audit on financial statements and for other specific purposes.

- protection of participants/beneficiaries - the new framework stipulates that the assets of the financial entities cannot constitute guarantees and cannot be used for granting loans or borrowings and that they are not included in the amount of the debt mass in case of bankruptcy and/or liquidation of the depositary, administrator or employer. Also, to increase the protection of the beneficiaries, the new laws provide establishing Guarantee Funds which will be made up of contributions from financial entities and will be used to pay the rights of participants and beneficiaries in case of impossibility to insure them by administrators.

- investment policy - the new drafts/ regulations provide a more prudent investment policy, designed to ensure, and satisfy the interests of participants, diversified directions and investment instruments, and stricter investment limits and prohibitions. At the same time, the investment policy, and any changes to it are made with the prior approval of the regulator. In this context, it is necessary to mention that all the new Laws provide one of the highest limits for investments made in Moldovan GS.

- transparency in the activity and informing the participants and beneficiaries - unlike the current regulations, the new draft laws provide tougher informing requirements for participants, namely: information and data that need to be made available to participants (investment profile, the investment policy, the profits obtained from the investment activity), as well as the publication of the information on the official website.

\section{CONCLUSIONS}

The GS market development of a country is interrelated with the development of its financial system. A poor financial market generates a very homogenous investor base on the GS market, and the experience of the Republic of Moldova is one of the countries that testify this assumption. In comparison to the Republic of Moldova, Romania has a more diversified investor base (nonresidents, individuals, financial investors which are represented not only by banks but by pension funds as well and in quite a significant proportion), which generates a more balanced GS market in comparison the Republic of Moldova and makes it less vulnerable in front of a certain category of investors.

To increase the development of the financial sector, and therefore the GS market, the Moldovan authorities started and are in the full process of an ambitious reform which is performed at the policy level for now. Implementing new regulations that are inspired by the international practices means establishing the same rules as on the international financial market that foreign investors are acknowledged and used to, which will increase their confidence in the financial sector of the Republic of Moldova and determine them to invest in this country.

However, after establishing a good and strong legal framework, the national authorities will have to take concrete measures at the macroeconomic level to stimulate the appearance of such players on the financial market and the GS market as well. It is necessary to mention that a challenge that the Moldovan authorities will have to face and to deal with, related to attracting/ diversifying the investors on the GS market, is the fact that 
beginning with 2021 the income obtained after holding GS instruments is going to be taxed. Such a fiscal policy may have a negative impact on attracting and diversifying the investors base on the Moldovan GS market, and the national authorities will have to make extra efforts in addressing this issue.

Besides creating financial investors, the Moldovan authorities should also stimulate the participation of individuals as investors on the national GS market. A good example from this perspective is Romania, the neighboring country that managed to develop 2 savings programs for its population that proved to be a great success. Such programs are a win-to-win incentive. The population gets diversified savings options and the state will get the necessary financial resources for its budgetary planning.

\section{WORKS CITED}

Law of the Republic of Moldova on banking activity no. 202/2017

Law of the Republic of Moldova on public sector debt, state guarantees, and state recrediting no. $419 / 2006$

Law of the Republic of Moldova on insurance no. 407/2006

Law of the Republic of Moldova on non-state pension funds no. 329/1999

Ministry of Finance of the Republic of Moldova. Investor's Guide in government securities. https://mf.gov.md/sites/default/files/ghidul_investitorului_in_vms.pdf

World Bank, International Monetary Fund. Developing a Government Bond Market https://elibrary.worldbank.org/doi/abs/10.1596/0-8213-4955-4

World Bank. Financial and Private Sector Development Global Capital Markets and Non-Bank Financial Institutions. http://documents1.worldbank.org/curated/en/238121468325297049/pdf/WPS6780.pdf

World Bank. Financing for Development Post-2015. http://documents1.worldbank.org/curated/en/206701468158366611/pdf/828000WP0Finan0Bo x0379879B00PUBLIC0.pdf

Received for publication: $\quad 22.09 .2020$

Revision received: $\quad 01.12 .2020$

Accepted for publication: $\quad 30.12 .2020$

\section{How to cite this article?}

Style - APA Sixth Edition:

Hincu, R., \& Litocenco, A. (2021, January 15). The importance of institutional investors diversification in the development of the government securities market. (Z. Cekerevac, Ed.) MEST Journal, 9(1), 28-36. doi:10.12709/mest.09.09.01.04

Style - Chicago Sixteenth Edition:

Hincu, Rodica, and Ana Litocenco. 2021. "The importance of institutional investors diversification in the development of the government securities market." Edited by Zoran Cekerevac. MEST Journal (MESTE) 9 (1): 28-36. doi:10.12709/mest.09.09.01.04.

Style - GOST Name Sort:

Hincu Rodica and Litocenco Ana The importance of institutional investors diversification in the development of the government securities market [Journal] // MEST Journal / ed. Cekerevac Zoran. Belgrade - Toronto : MESTE, January 15, 2021. - 1 : Vol. 9. - pp. 28-36. 
Style - Harvard Anglia:

Hincu, R. \& Litocenco, A., 2021. The importance of institutional investors diversification in the development of the government securities market. MEST Journal, 15 January, 9(1), pp. 28-36.

Style - ISO 690 Numerical Reference:

The importance of institutional investors diversification in the development of the government securities market. Hincu, Rodica and Litocenco, Ana. [ed.] Zoran Cekerevac. 1, Belgrade - Toronto : MESTE, January 15, 2021, MEST Journal, Vol. 9, pp. 28-36. 